\title{
State Practice Notes on Korea
}

\author{
The Procedure for the Compulsory Execution of the Ruling on Nippon Steel to \\ the Victims of Forced Mobilization during the Japanese Colonial Period
}

\author{
Daehun Kim*
}

On June 3, 2020, South Korea's Pohang Branch Court of the Daegu District Court (Pohang Branch Court) announced through the media that on June 1, it served Nippon Steel ${ }^{1}$ by public notice documents of the court ruling. It included the seizure of the company's assets in order to compensate for damages caused to the Korean forced labor victims during the Imperial Japanese occupation.

Service by public notice is a process by which a party to a lawsuit gives an appropriate notice of legal action to another party, and the other party is presumed to have been served even if a fixed time on the service has elapsed. This is the first time a Korean court decided upon the service of process directly to a Japanese private company on the issue of reparation for damages to forced labor victims.

After one year and ten months since October 30, 2018, when the Supreme Court of South Korea rendered its en banc judgment acknowledging Nippon Steel's liability for reparation to victims of forced mobilization (Judgment on Forced Mobilization), the Pohang Branch Court's decision allowed the victims to begin the procedure for receiving substantial compensation for the harm they suffered. The 2018 Judgment on Forced Mobilization became a significant turnaround from the Agreement on the Settlement of Problem concerning Property and Claims and the Economic Cooperation between the Republic of Korea and Japan (1965) (Claims Agreement) because it officially acknowledged the individual rights of the victims of forced-mobilization to claim reparations.

* Third Year Graduate Law Student, Inha University Law School, Korea.

1 The current Nippon Steel Corporation was formed with the merger (2012) of the original Nippon Steel (founded in 1970) and Sumitomo Metal Industries (founded in 1935), and the name of the merged company was changed from Nippon Steel \& Sumitomo Metal Corporation to Nippon Steel Corporation in 2019. The original Nippon Steel originated in a war criminal company during the Imperial Japanese occupation. At present, Nippon Steel and Posco, a Korean steelmaker, have strategic partnerships with each other, through the joint purchase of raw materials, joint R\&D, and technological exchange, withholding $3.5 \circ \%$ and $5.05 \%$ of the other company's shares, respectively. 
Even though the Supreme Court rendered the judgment at that time, there were many hurdles to overcome. There were difficulties regarding the terms of diplomacy and international law and the actual procedure for financial reparation to the victims because the seized assets of Nippon Steel in South Korea could not be liquidated due to the lack of cooperation by the Japanese government.

However, as a result of the Pohang Branch Court's decision on the service by public notice upon Nippon Steel, the judiciary's judgment on the "issue of forced mobilization" by Japanese private companies has shifted from determining the right or wrong on "the issue of forced mobilization," to whether the Japanese companies' assets seized in South Korea can be liquidated to substantially compensate the victims. This problem has become a very important issue for domestic companies doing business with Japan, since, according to data released by the Prime Minister's Office in 2012, 299 companies connected with Japanese war crimes currently exist.

Therefore, this note aims to review the procedure for compulsory execution under South Korean law, focusing on the process that has developed after the Supreme Court's 2018 Judgment on Forced Mobilization.

The Status of Progress after the Supreme Court's 2018 Judgement on Forced Mobilization

On January 4, 2019, at the victims' request, a follow-up action after the Supreme Court's ruling on reparations for damages was established. In October 2018, the Pohang Branch Court ruled in favor of seizing Nippon Steel's shares in PNR, ${ }^{2}$ a joint venture of Nippon Steel and POsCO, and on January 4, 2019, an order of seizure, and a copy of the ruling on stock seizure was served upon PNR. Finally, on January 10, 2019 the seizure became effective. ${ }^{3}$

Afterward, on January 22, 2019, the Pohang Branch Court requested the National Court Administration to serve the written stock-seizure decision of this case to Nippon Steel, and the National Court Administration sent to the

2 PNR (POSCO-Nippon Steel RHF Joint Venture, Co. Ltd.) is a joint venture established in association with Nippon Steel in January 2008 for the recycling of ferrous metallurgy byproducts.

3 Civil Execution Act, Article 227 (Seizure of Monetary Claim) (3) An order of seizure shall take effect upon a service on the garnishee. 
Japanese Ministry of Foreign Affairs the "Request for the Service Abroad of Judicial and Extrajudicial Documents" dated January 25, 2019, which included the written stock-seizure decision of this case. However, while the Japanese Ministry of Foreign Affairs received the above Request for Service Abroad on February 7, 2019, it did not proceed with the procedure for serving the documents upon the head office of Nippon Steel for over five months and returned the Request for Service Abroad to South Korea's National Court Administration without specifying any reason. To this end, on August 6, 2019, counsel for the victims submitted to the Pohang Branch a written request asking for re-service of the documents.

On May 1, 2019, counsel filed in the Pohang Branch Court, a request for a sale order regarding the seized shares of Nippon Steel in PNR. Accordingly, on June 18, 2019, in the above case of compulsory execution (request for sale order), the Pohang Branch Court issued against Nippon Steel a written examination to the effect that the company should present an opinion, if any, in writing with regard to the request for sale order within 6 o days from the arrival of that document; the court, however, did not receive any reply. On June 1, 2020, the Pohang Branch Court served upon Nippon Steel the documents of asset seizure for compensation to the Korean victims of forced mobilization.

Regarding the above process up to the court's service by notice, some criticized the court for the extended time and the complicated procedure required for the substantial reparation of the victims, despite the fact that Nippon Steel's liability for reparations had already been acknowledged in 2018. However, the court's process of execution is not an area for value judgement, but a practical area of administration that requires specific and elaborate rules to operate. Therefore, the criticism against the court should start with examining whether the court's process of execution was proper in view of the lower-level rules or the court's practical criteria for the decision, which are the grounds for the court's execution.

\subsection{Legal Review of the Process of the Court's Compulsory Execution}

Under South Korean law, the creditor's self-help against the party in default is not permitted. The creditor should file a lawsuit in a court to receive a final and conclusive judgment, or apply to an executing agency for execution by a notary deed with executory force. In the event of the creditor's application for execution, the court: first, seizes the garnishee's property to prevent its disposition; second, compulsorily liquidates the property by sale or by similar means if the debtor fails to perform its obligation; and finally, makes reimbursement to the creditor by distribution. The compulsory execution under Korean law 
progresses in three stages, and is stipulated under the Civil Procedure Act, the Civil Execution Act, and detailed enforcement regulations.

The defendant, Nippon Steel, refused to make direct monetary compensation to the victims in compliance with the ruling of the Supreme Court. The victims' counsel chose to seize the shares of Nippon Steel in PNR, which is a joint venture formed by Nippon Steel, the Japanese company and debtor, and POsCO, a Korean company. From a legal point of view, the victims' counsel had no problem with the application of Korean domestic law, because the target of seizure was Nippon Steel's assets located in South Korea.

Nippon Steel, however, showed no response to the seizure at the first stage. The victims of forced mobilization filed in the competent Pohang Branch Court requested a sale order regarding the seized shares of Nippon Steel in PNR. The second stage of the procedure for compulsory execution, which is the encashment, is on the basis of the effect of the lawful seizure.

The request for sale order filed by the plaintiff corresponds to the method of special encashment. ${ }^{4}$ The reason for this request is when there is difficulty in the collection because the shares of Nippon Steel in PNR to be liquidated are unlisted shares, which are not tradable in the market.

In principle, according to the Civil Execution Act, the court shall examine the debtor before rendering the ruling on permitting request for special encashment. However, although the competent court of the Judgment on Enforced Mobilization sent a written examination to the defendant, Nippon Steel, in order to hear its opinions according to the principle, it did not receive a reply.

Cases like this are treated as exceptional by the Civil Execution Act, where the examination (return of reply) may be dispensed with. The provision of Article 241(2) of the Civil Execution Act specifies, "Provided, that when the debtor stays in a foreign state or his/her whereabouts is unknown, such examination may be dispensed with." Therefore, the court can judge that the procedure for examination may be dispensed with respect to the case of Nippon Steel, a debtor that resides in a foreign country.

Considering the ruling on service by public notice made by the competent court of the Pohang Branch Court on January 6, 2020, it may be viewed as a

4 Article 241 (Method of Special Encashment) (1) of the Civil Execution Act stipulates, "When a seized claim is on a conditional basis or subject to time limit, is connected with a performance of a counter obligation, or is impracticable to be collected for other reasons, the court may issue any of the following orders, upon a motion of the creditor," and it may be said that unlisted shares like shares of PNR come under "when a seizure claim is impracticable to be collected for other reasons" of Article 241 (1). 
decision based on the above legal review leading to the judgment that the procedure for examination may be dispensed with provided however, some additional review since the defendant is Nippon Steel a foreign, Japan-based corporation located in Korea.

\subsection{Review on Procedure for Service Prescribed by International Law \\ 2.2.1 General Law and Special Law Applicable to Service Perfected in a Foreign Country}

The service by public notice refers to a system in regards to a specific situation if a junior administrative officer of a court keeps the document to be served, and posts the reasons on the court's bulletin board. The service can be otherwise perfected in such manners as prescribed by Supreme Court Regulations, the complaint is deemed as having been served upon the defendant, even though the complaint is not delivered to the defendant.

Within South Korean law, the Civil Procedure Act stipulates the principles of service by public notice. It specifies methods for effecting the service in a foreign country as well as in South Korea. First, in the case of service perfected in a foreign country, it shall be entrusted by the presiding judge of a Korean court to the Korean ambassador, minister or consul stationed in the relevant foreign country or the competent government authorities of the country. However, if it is impossible to comply with the provisions of Article 191, or deemed ineffective at least, even if the provisions are complied with because a junior administrative officer of a court may, either ex officio or upon request from the parties, make service by public notice. Moreover, if service by public notice is made in a foreign country under the provision, the service by public notice takes effect with the lapse of two months. Therefore, it may be said that service upon a corporation in a foreign country is permissible, if the provisions of service in the Civil Procedure Act are applicable. However, if there is any special law regarding the service to be perfected in a foreign country, the special law prevails over the general law, as the way it is with other laws and regulations.

Special laws regarding the service to be perfected in a foreign country are the Act on International Judicial Mutual Assistance in Civil Matters and its lower Regulations on International Judicial Mutual Assistance in Civil Matters. These special laws, however, are applicable only in case where are no treaties on service that have been concluded, and if there is any treaty on service between South Korea and another country, the treaty takes priority in application. Therefore, judgment about the legality of service by public notice perfected upon Nippon Steel by the court requires review based on the service treaty signed between South Korea and Japan. 
2.2.2 Procedure for Service Based on the Hague Service Convention

Currently, South Korea and Japan are members of the Convention on the Service Abroad of Judicial and Extrajudicial Documents in Civil and Commercial Matters (Hague Service Convention), and service in both countries are legally judged according to the Hague Service Convention.

The Hague Conference on Private International Law, which was created in 1893, has made efforts to unify the rules of private international law. As one such effort, the Hague Service Convention, one of Hague Civil Procedure Conventions, was concluded in 1965. South Korea also joined the Hague Service Convention in 2000, and it reflected service abroad procedures based on the Hague Service Convention in the Bylaws on International Judicial Mutual Assistance in Civil Matters.

In principle, the Hague Service Convention's entrustment should be made by the method of indirect implementation via a governmental agency of the entrusted country. Specifically, the procedure for service from South Korea to a foreign country is as follows: (1) domestic court of lawsuit; (2) president of court; (3) National Court Administration; (4) a central agency of the entrusted country (ministry of legal affairs, ministry of foreign affairs, etc. in the relevant country; and (5) a relevant court in the entrusted country.

Currently, Japan is also a member of the Hague Service Convention and complies with the convention. Therefore, in the Judgment on Forced Mobilization, service upon Nippon Steel progresses through the following stages: Pohang Branch Court to the President of Daegu District Court to the National Court Administration to the Japanese Ministry of Foreign Affairs to a Japanese court. However, the Japanese Ministry of Foreign Affairs delayed service. The question is whether there is any exception to avoid the delay and service of the documents upon Nippon Steel under the Hague Service Convention.

\section{2 .3}

Whether Service Can Be Perfected by the Method of Direct Implementation

According to the Hague Service Convention, in principle, a foreign country's service should be made by the indirect implementation method. In certain cases, however, it is possible to effect service directly through consular agents in a foreign country because the Hague Service Convention explicitly permits each contracting state to effect service through its diplomatic or consular agents not only upon a national of the State in which the documents originate, but also upon other persons abroad. This is provided, however, that the Convention allows any State to declare that it is opposed to such service within its territory, unless the document is to be served upon a national of the State in which the documents originate. 
At the time of signing of the Hague Service Convention, South Korea declared its opposition under Article 8 of the Convention. ${ }^{5}$ It blocked the way for another Contracting State to serve documents upon persons within the territory of South Korea other than a national of the State in which the documents originate.

There is no doubt that the Hague Service Convention does not prescribe the strict principle of reciprocity. However, given that reciprocity is the basis for international relations, it is viewed that service by the direct implementation method should be restricted to Korean nationals. Therefore, it is deemed difficult to excuse the Japanese Ministry of Foreign Affairs and adopt the method of direct service upon Nippon Steel.

Possibility of Domestic Ruling without Effecting Service

Service abroad will infringe upon the interests of the party abroad because it usually takes a long time. Therefore, Article 15 of the Hague Service Convention stipulates special rules connected with a case where no certificate of service has been received within a fixed period.

It provides that each Contracting State shall be free to declare, that even if no certificate of service or delivery has been received, the judge may give judgment if: (1) the document was transmitted by one of the methods provided for in the Hague Service Convention; (2) a period of not less than six months, considered adequate by the judge in the particular case, has elapsed since the date of the transmission of the document; and (3) no certificate of any kind has been received, even though every reasonable effort has been made to obtain it through the competent authorities of the State addressed.

To examine the Judgment on Forced Mobilization case, it is deemed that the Korean court may give judgment under the Hague Service Convention's special rules because (1) the written examination was transmitted to Nippon Steel under the Hague Service Convention; (2) a period of more than six months has elapsed since June 18, 2019, the date of the transmission of the written examination; and (3) it seems that every reasonable effort has been made to obtain a certificate through the Japanese Ministry of Foreign Affairs. Therefore, it is

5 Article 8 of the Convention on the Service Abroad of Judicial and Extrajudicial Documents in Civil or Commercial Matters (Hague Service Convention) states that "Each Contracting State shall be free to effect service of judicial documents upon persons abroad, without application of any compulsion, directly through its diplomatic or consular agents. Any State may declare that it is opposed to such service within its territory, unless the document is to be served upon a national of the State in which the documents originate." 
judged that the Korean court's service by public notice upon Nippon Steel is lawful since it does not violate the Hague Service Convention.

\section{The Future Prospects of Procedure for Execution}

Given that the South Korean court's decision regarding service by public notice upon Nippon Steel was lawful, after midnight of August 1, when two months passed since the court decided that service by public notice upon the debtor Nippon Steel, documents relating to seizure were regarded as having been served upon Nippon Steel. The court will be able to decide on the sale of the seized shares of Nippon Steel in PNR. If there is no problem after that, the court seizure and sale of the shares usually and quickly provides the victim with compensation.

However, it is highly likely that the process that follows service by public notice will not be smooth. POSCO, another shareholder of PNR, can suspend the execution process by immediate appeal to the decision to sell Nippon Steel's PNR stake, and it will take a long time to liquidate the stock because the challenges of assessing the value of unlisted stock.

In case where there is no problem with the Compulsory Execution, during the period up to that time, the court will evaluate Nippon Steel-owned shares in PNR as preparation for deciding on their sale. If a result of the evaluation, the indemnity claim of enforced-mobilization victims and procedural expenses are found to be reimbursable with the proceeds of the sale to be seized, the court may give the order for sale two months after the service by public notice was perfected.

If the seized assets are sold, and an execution officer of the court receives the proceeds of the sale of the seized shares in PNR, it shall be deemed that Nippon Steel has paid damages to the victims of the forced mobilization at the time of receiving the proceeds. After that, the execution officer will present the proceeds of sale and the protocol of sale to the execution court, and when the proceeds of the sale are presented, the distribution procedure will be commenced by the execution court. Through this, the victims will be financially compensated.

\subsection{Possibility of Posco's Immediate Appeal to the Decision to Sell the Nippon Steel's PNR Stake}

An immediate appeal means an application for non-compliance with a decision or order concerning the proceedings of a lawsuit and is only possible if it is prescribed by law. The sale of PNR shares follows the method of special 
encashment. Moreover, the statute stipulates that an immediate appeal can be made for the decision to special encashment.

In general, an immediate appeal has the effect of suspending the execution. However, in the compulsory execution procedure, it does not have the effect of suspending the execution. Indiscriminately denying the suspension's validity could cause irreparable damage to the complainant, so the court acknowledges the effect of suspending the decision's validity by blocking the decision itself in the case of a trial in which it is valid only when confirmed in practice.

The order for special encashment of the stock at issue in this matter will only take effect if confirmed. Hence, an immediate appeal to the decision of special encashment will result in the suspension of execution without a separate suspension. The execution may be suspended if an immediate appeal is made within one week from the court's decision to allow the sale.

Commonly, a person who can make an immediate appeal to a special encashment order is the debtor. Currently, however, the debtor (Nippon Steel) has not responded to the South Korean court's action, so it is questionable who can make the immediate appeal. Based on the Supreme Court's precedent, the creditors can immediately appeal to reject the special encashment order. It can be interpreted that a person whose legitimate interests have been violated in consideration of the purpose and interests of the compulsory execution system can make an immediate appeal.

According to the interpretation of this precedent, POsco, which established a joint venture with Nippon Steel, can immediately appeal to stop the compulsory execution. Because the forced sale of its business partner's (PNR) stake would force the company to change its business partner, resulting in severe damage to the development of new technologies and profit-making, it sought to obtain in cooperation with Nippon Steel. If the court cites Posco's immediate appeal, the decision to sell the stock will be suspended, and if POsCO appeals the court's decision, the trial is likely to proceed for years again.

\subsection{The Possibility of a Prolonged Delay in the Sale of Unlisted Shares}

The PNR shares of Nippon Steel, which the victims of forced labor intend to seize and sell, are unlisted shares. It is challenging to assess the value of unlisted stocks because they do not have the market price of publicly traded listed shares. Therefore, the court will evaluate the value of unlisted shares with financial statements and evidence that show its financial position. However, even if the court assesses the value through this process, it is challenging for the shares to sell.

In general, the seized shares are sold at auction. However, most unlisted stocks have been auctioned off, continuing to lose value compared to the 
original valuation because the investors who want to purchase shares think unlisted stocks are less reliable than listed shares.

Furthermore, the unlisted companies do not disclose all information transparently, which can cause significant losses and cause difficulties for investors to resell purchased shares. If it becomes challenging to sell the stock at auction, the victims may obtain a bond by taking over the shares and becoming a direct shareholder. However, it will take at least several years, making it difficult to compensate the victims quickly.

\section{5}

\section{Conclusion}

Through the en banc judgment on forced mobilization, the Korean judiciary seems to have consolidated its stance on the exclusion of compensation for Korean individuals from the 1965 Claims Agreement. It is thought that this stance will also be maintained in possible lawsuits against Japan to be filed by victims of forced mobilization in the future.

Further, the decision of service by public notice rendered by the court in 2020 is significant in that compulsory execution to substantially compensate the victims has become enforceable regardless of the attitudes of Japanese companies that refuse to give reparations to the Korean victims of forced mobilization during the Imperial Japanese occupation, and the refusal of the Japanese government to serve process to its companies. Nonetheless, the Korean court's decision took too much time to be processed. Because the period of the litigation for the victims has taken as long as 23 years, (including litigation in Japan) it is hard to predict how many more years it will take for full compensation for the victims if an immediate appeal is made for a suspension of compulsory execution. The sale of unlisted stocks will be inevitably delayed.

These dire consequences occurred because the South Korean judiciary prioritized political judgment, which considered diplomacy and domestic political relationships, over the realization of justice for the victims of forced mobilization and military sexual slavery during the Imperial Japanese occupation.

As a representative example, the en banc judgment for reparations was not established until 2018, five years after Nippon Steel appealed against the 2013 ruling on the reparation of victims of forced mobilization due to the Park Geun-Hye administration's pressure on the judiciary. During the period of delay of the court's judgment, as many as three of the four victims of forced mobilization died of old age.

After the Korean court decided upon service by public notice upon Nippon Steel, the Japanese government responded that it will review every option 
available to it. Given that Japan's export restrictions on South Korea in 2019 were a disguised retaliation to the 2018 court ruling for compensation for Korean victims, it is likely that Japan will retaliate by similar means again.

However, it is believed that the judiciary judgment and decision should be made through a fair process based on the law, apart from political issues because it is the fundamental principle of the Korean Constitution. It clearly reflects its stance on the separation of powers, that political and diplomatic problems regarding a judgment rendered through a fair process should be settled by the administration and the legislature. It is hoped that the court's ruling on the service by public notice upon Nippon Steel will become a momentum to set right the foundation of the judiciary, that is, the realization of justice. 